\title{
Synergistic of antimicrobial activities of lactic acid bacteria in fermented Tilapia nicoliticus incorporated with selected spices
}

\author{
${ }^{1}$ Ismail, A., ${ }^{1,3,{ }^{*} \text { Lani, M.N., }}{ }^{2}$ Zakeri, H.A., ${ }^{2}$ Hasim, N.N., ${ }^{4}$ Alias, R. and ${ }^{5}$ Mansor, A. \\ ${ }^{1}$ Faculty of Fisheries and Food Science, Universiti Malaysia Terengganu, 21030 Kuala Nerus, Terengganu, \\ Malaysia \\ ${ }^{2}$ Faculty of Science and Marine Environment, Universiti Malaysia Terengganu, 21030 Kuala Nerus, \\ Terengganu, Malaysia \\ ${ }^{3}$ Institute of Marine Biotechnology, Universiti Malaysia Terengganu, 21030 Kuala Nerus, Terengganu, \\ Malaysia \\ ${ }^{4}$ Institute of Bio-IT Selangor, Universiti Selangor, Jalan Zirkon 7A, Seksyen 7, 40000 Shah Alam, Selangor, \\ Malaysia \\ ${ }^{5}$ Enzyme and Fermentation Technology Programme, Food Science and Technology Research Centre, \\ MARDI Headquarters, 43400 Serdang, Selangor, Malaysia
}

\begin{abstract}
Article history:
Received: 2 November 2020

Received in revised form: 9

December 2020

Accepted: 3 February 2021

Available Online: 30 May 2021
\end{abstract}

\section{Keywords:}

Antimicrobial Activity,

Spices,

Fermented Fish,

Lactic Acid Bacteria,

Natural Preservatives.

DOI:

https://doi.org/10.26656/fr.2017.5(3).534

\section{Introduction}

Food contamination has been the biggest concern for consumers for a long time. It has been shown that food contamination can either come from microbiological or chemical origins. For this reason, there has been intensive and continuous research to get knowledge about contamination sources and the way to prevent them. One of the food contamination sources is due to pathogenic bacteria. This type of contamination has become a global concern because it can affect human health (Rather et al., 2017; Salleh et al., 2017). Ninety per cent of foodborne illnesses are caused by contamination (Barbudhe et al., 2003; Arul and Saravanan, 2011). Food products may transmit certain microorganisms and cause foodborne illnesses in several ways, including through infections, intoxications or toxicoinfections (Knechtges, 2012). An infection happens when a pathogenic bacterium present in food is ingested and then multiplies, as is true for Salmonella, Campylobacter, Listeria and some enteropathogenic Escherichia coli. Most foodborne illnesses are infections caused by bacteria, viruses and parasites.

The global demand for fish and fish-based products has increased and several changes such as vulnerability 
and susceptibility to oxidation, and seasonal availability have resulted in the development of preservation methods (Zang et al., 2016; Yu et al., 2018). Among other preservation methods such as freezing, salting and smoking, fermentation, in particular, has been the most widely used (Panda et al., 2011). In modern terms, fermented fish is defined as fresh fish that has undergone a series of desirable biochemical changes through the action of microorganisms or enzymes. These changes include acidification (carbohydrate catabolism), gelation of myofibrillar and sarcoplasmic proteins of muscle, and degradation of proteins and lipids. Usually, all these fermented fish products were traditionally produced based on empirical knowledge without any knowledge of the microbes involved in the process until the development of modern microbiology (Mouritsen et al., 2017). There are different types of fermented fish products according to the final product appearance. Fermented fish can be divided into three groups: Fermented as a whole or in pieces such that the fish retains as much of its original structure as possible (Zeng et al., 2013), fermented fish pastes where the fish are converted into paste-like products (Giri et al., 2010) and fermented fish sauce where the fish are completely converted into liquid form (Lopetcharat et al. 2001).

Fermented fish has a long history in Europe and North Africa, but now Southeast and East Asian countries are the leaders in its production (Zang et al., 2020). In Malaysia, a type of fermented fish known as Pekasam, is a fermented whole fish product prepared by mixing freshwater fish with salt and ground roasted uncooked rice. A minimum amount of salt should also be used, and then the fish undergo different fermentation periods (2-3 weeks or 12 months) to make different products. A longer fermentation period can produce better products (Ezzat et al., 2015).

Lactic Acid Bacteria (LAB) have been isolated from many fermented foods to be used as probiotics and functional food materials (Solieri et al., 2014). The main LAB groups are Gram-positive, catalase-negative organisms and belong to genera Lactobacillus, Bifidobacterium, Lactococcus and Leuconostoc (Leroy and De Vuyst, 2004). LAB are able to produce acids, hydrogen peroxide and bacteriocins that possess great potential as food biopreservatives (Aslim et al., 2005). Probiotics are live microorganisms and non-pathogenic. If they are administered in adequate amounts, it will give balance and health benefits to the host (Food and Agriculture Organisation and World Health Organization, 2001). A study from Paludan-Muller et al. (2002) showed the potential of LAB that could be isolated from fermented fish.
Bacterial growth and lipid oxidation are the main factors that determine food quality loss and shelf-life reduction (Tajkarimi et al., 2010). To reduce these problems, chemical additives are commonly used in food products to extend their shelf life. However, consumers have growing concerns about health-related issues associated with the use of synthetic antimicrobial/ antioxidant agents (Aziz and Karboune, 2016). In order to satisfy the consumers' demands and restore their confidence in the safety of food products, the food industry was motivated to look for natural alternatives that exhibit strong antimicrobial and/or antioxidant properties (Fernandez-Lopez et al., 2005; Ahmad et al., 2019). There are a few natural sources that can be used, such as spices (cinnamon, clove, nutmeg, ginger, black pepper, garlic etc.) and plant extracts (tea, grape seed, cranberry, blueberry, strawberry and rosemary) that contain antioxidant components and can be used as natural antioxidant agents to inhibit lipid oxidation in food products (Brewer, 2011; Jiang et al., 2011). Some natural antioxidants/antimicrobials are able to extend the shelf life of food products (Salleh et al., 2021). Natural preservatives are easily accessible by the community and implemented sustainably through awareness and scientific merits and the ingredients also have been used as sustainable alternative to synthetic food preservatives.

Spices are normally used as flavouring agents, medicine, preservatives as well as colouring agents. Extract of spices hold preservatives and natural antioxidant properties, and also have antibacterial, antifungal and antiviral activities (Hernández et al., 2011). Spices stabilise food from microbial deterioration by making the microbial growth progressively slower and eventually totally suppressed (Souza et al., 2005). Most of the existing preservatives are based on synthetic chemicals. Anand and Sati (2013) reported that the application of some spices as preservatives in food are conducted to determine its efficiency since spices are natural sources and can be used to replace synthetic preservatives in food, such as nitrates, which have been claimed to possess negative effects on human health.

Tilapia fish was a common fish and widely used in Malaysian cuisine and was abundantly found all over the country. Tilapia has been identified as one of the main species for freshwater aquaculture in the Third National Agriculture Policy (DPN3) (Hamli et al., 2013). Based on the report by Awang (2001), fermented fish from freshwater fish is more popular than marine fish due to their flavour and texture. Small-sized tilapia of less than $350 \mathrm{~g}$ per fish is suitable for fermentation. The selection of tilapia in this study because this fish can survive in different culture systems, disease resistant and tolerate 
unfavourable conditions of water (Attalla, 2001), suggesting this type of fish is suitable for large scale commercial fermented fish.

However, the effect of LAB that is isolated from fermented Tilapia nicoliticus and added with a selected spice has never been reported. This research was conducted to observe a potential natural food preservative using LAB from fermented fish incorporated with various spices (turmeric, chilli and black pepper).

\section{Materials and methods}

\subsection{Fermented Tilapia (Tilapia nicoliticus) preparation}

Fermented tilapia was prepared and the recipe for ingredient was referred to Noor 'Izzati (2013). The tilapia weighed between $300 \mathrm{~g}$ to $350 \mathrm{~g}$ was obtained alive from a local fresh market and placed directly in iced water. The fermented tilapia products were prepared according to the procedures of the fermented fish industry as stated by Awang (2001) but the salt used was reduced to $20 \%$. The fermented fish was prepared according to the ingredients listed in Table 1. Fresh spices used in the study were purchased from a local Hock Kee Seng market in Gong Badak, Kuala Terengganu, Malaysia. Then, black pepper, chilli and turmeric in powder form were mixed with the fermented tilapia.

Table 1. The fermented tilapia fish ingredients and spices incorporated with fermented tilapia fish give the highest reduction of total plate count based on a study by Noor 'Izzati (2013)

\begin{tabular}{lcc}
\hline Ingredients & $\begin{array}{c}\text { The percentage (\%) } \\
\text { (based on fish weight) }\end{array}$ & Weight (g) \\
\hline Fish & 100 & $\sim 300-350$ \\
Salt & 20 & 65 \\
Crushed roasted rice & 20 & 65 \\
Asam gelugur & 5 & 16.25 \\
(Garcinia atroviridis) & 5 & 16.25 \\
Brown sugar & & \\
\hline Spices & 9 & 29.25 \\
Black pepper & 6 & 19.5 \\
Chilli & 9 & 29.25 \\
Turmeric & &
\end{tabular}

Fermented tilapia without any spices were used as control. The spices had undergone UV treatment under a laminar airflow cabinet (ERLA-CFM SERIES, VFM-4, Malaysia) for 30 mins before being mixed with the fish in order to reduce microbial contamination (Nicorescu et al., 2013). After that, the tilapia with spices was placed in a sterile-labelled plastic container to undergo fermentation and fermented at ambient temperature (30 $37^{\circ} \mathrm{C}$ ) for 15 days. During the fermentation process, the samples were withdrawn (300 g to $350 \mathrm{~g}$ ), then homogenised and placed into a sterile container on the predetermined day from day 1 until day 15 . The samples of fermented tilapia were placed into a sterile rectangular plastic container with Lid $1000 \mathrm{~mL}(115 \times 165 \times 71 \mathrm{~mm})$ and transported immediately to the laboratory for microbiological analysis.

\subsection{Isolation of lactic acid bacteria (LAB) from fermented Tilapia nicoliticus}

For isolation purposes, $10 \mathrm{~g}$ of sample was homogenised in $90 \mathrm{~mL}$ of sterile normal saline $(0.85 \%$ $\mathrm{NaCl}$ ) solution. The homogenates were aseptically prepared using a stomacher at high speed for 3 mins. Next, $1 \mathrm{~mL}$ of sample from the stomacher bag was added into $9 \mathrm{~mL}$ of MRS broth and the sample solution was incubated at $30^{\circ} \mathrm{C}$ for $48 \mathrm{hrs}$ in anaerobic condition. Then, serial dilution was made in a normal saline solution from $10^{-1}$ to $10^{-6}$. An amount of $0.1 \mathrm{~mL}$ of sample was spread on MRS agar (Merck, Germany), MRS agar with $0.8 \% \mathrm{CaCO}_{3}, \mathrm{M} 17$ agar (Oxoid, UK), and Tomato Juice Agar (TJA) (Oxoid, UK) following the method of Aween et al. (2012). Then, the plates were incubated anaerobically at $37^{\circ} \mathrm{C}$ for $48 \mathrm{hrs}$. Different morphology of the colony which dissolved $\mathrm{CaCO}_{3}$ and formed a clear zone on the medium was purified by streaking on different plates to get a single colony. Then, the plates were incubated again at $37^{\circ} \mathrm{C}$ for $48 \mathrm{hrs}$ under anaerobic condition using a $\mathrm{CO}_{2}$ incubator (Memmerth INC 153, Germany). The different morphology of the colonies on the plates had undergone a confirmation test (modified from Panthavee et al., 2007).

\subsection{Antimicrobial activity of cell free supernatant (CFS) of LAB by well diffusion method}

The antimicrobial activity of the cell-free culture supernatant (CFS) was determined using agar well diffusion assay (Liasi et al., 2009). Firstly, one loop of the LAB was grown in $10 \mathrm{~mL}$ MRS broth in a centrifuge tube. CFS for the antibacterial assay was obtained after centrifugation at $8,000 \mathrm{rpm}$ for $15 \mathrm{mins}$ at $4^{\circ} \mathrm{C}$ by using a laboratory refrigerated centrifuge (Gyrozen, Korea). Well diffusion method used Mueller Hinton (Merck, Germany) as the medium for tested pathogens. The tested pathogens were prepared by mixing them with $0.85 \% \mathrm{NaCl}$ and their concentration was adjusted to 0.5 MacFarland standard. The American Type Culture Collection (ATCC) test strain of bacteria was used for this assay which is Escherichia coli ATCC 11775, Staphylococcus aureus ATCC 25923, Bacillus cereus ATCC 14579 and Salmonella enterica serovar Typhimurium ATCC 14128. After that, the bacterial suspensions were swabbed onto MHA by sterile cotton swabs. Then, the wells of $6 \mathrm{~mm}$ diameter were made using cork borers. One drop of molten Mueller Hinton 
Agar (MHA) was added into each well for lining purposes. Approximately $50 \mu 1$ of LAB supernatant were added into the wells and the plates were incubated at $37^{\circ}$ $\mathrm{C}$ for $24 \mathrm{hrs}$. After $24 \mathrm{hrs}$ of incubation, the diameters of inhibition zones were measured following the method by Liasi et al. (2009).

\subsection{Statistical analysis}

The data were expressed as mean \pm standard error (SE). Results were analysed by multiple comparisons two-way analysis of variance (ANOVA) using Tukey's test, Graph Pad Prism 5 where probability $(\mathrm{p}<0.05)$ considered statistically significant.

\section{Results and discussion}

3.1 Lactic acid bacteria (LAB) count of fermented tilapia fish against different periods of fermentation on various types of agar

The microbial count of LAB in fermented tilapia incorporated without spices (control), 9\% black pepper, $6 \%$ chilli and $9 \%$ turmeric on MRS agar is shown in Figure 1.

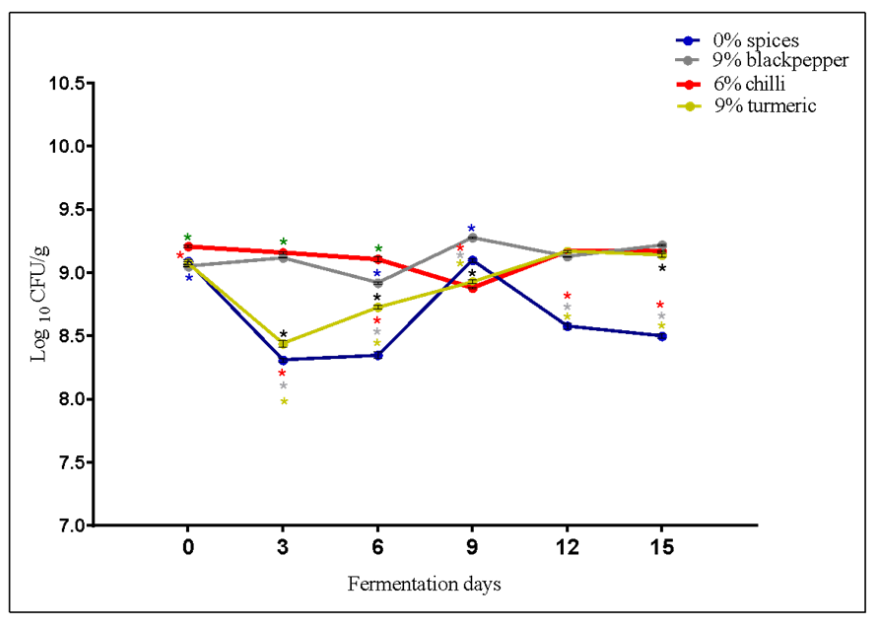

Figure 1. Growth of LAB in fermented tilapia $\left(\log _{10} \mathrm{CFU} / \mathrm{g}\right)$ incorporated without spices, $9 \%$ black pepper, $6 \%$ chilli and $9 \%$ turmeric on MRS agar. Data are mean of triplicated $(n=$ 3) indicating standard error (SE)

Fermented tilapia with chilli showed the highest number of LAB during 6 days of the fermentation. Meanwhile, for day 9 and day 15, black pepper showed the highest LAB count for MRS agar. However, on day 12, chilli showed a slightly higher microbial count compared to black pepper and turmeric. The control showed the lowest microbial count from start until the end of the fermentation period. From Figure 1, the highest count of LAB microbial count was noticed on day 9 of fermentation with the black pepper's fermented tilapia.

Comparatively, the highest number of microbial counts on the MRS with $\mathrm{CaCO}_{3}$ agar was observed in fermented tilapia incorporated with turmeric on day 0 , followed by chilli on day 3 and day 6 (Figure 2). However, from day 9 until day 15, the highest microbial count was observed in fermented tilapia incorporated with black pepper. On day 0 and day 9, the highest number of $\mathrm{LAB}$ count on MRS with $\mathrm{CaCO}_{3}$ agar was observed in fermented tilapia incorporated with turmeric and black pepper, respectively.

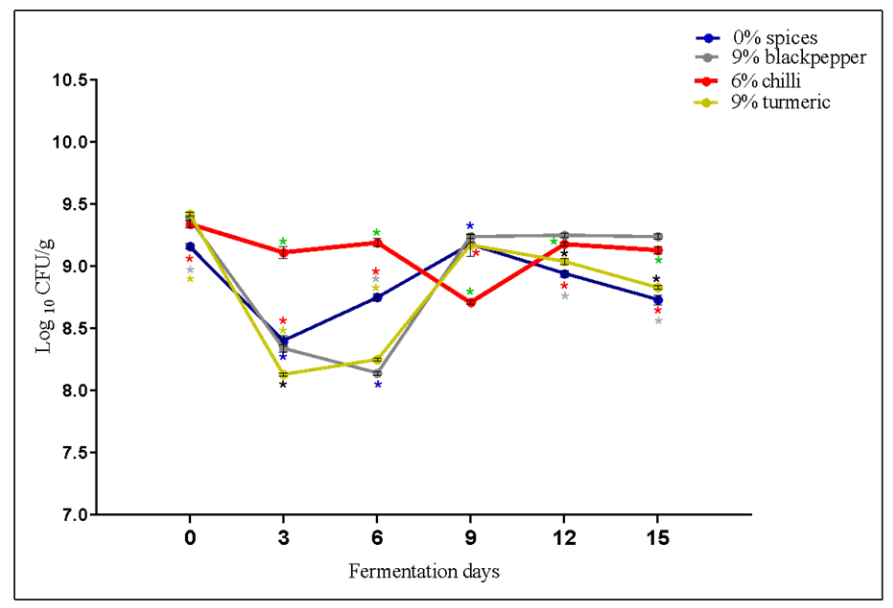

Figure 2. Growth of LAB in fermented tilapia $\left(\log _{10} \mathrm{CFU} / \mathrm{g}\right)$ incorporated without spices, $9 \%$ black pepper, $6 \%$ chilli and $9 \%$ turmeric on MRS with $\mathrm{CaCO}_{3}$ agar. Data are mean of triplicated $(n=3)$ indicating standard error $(\mathrm{SE})$

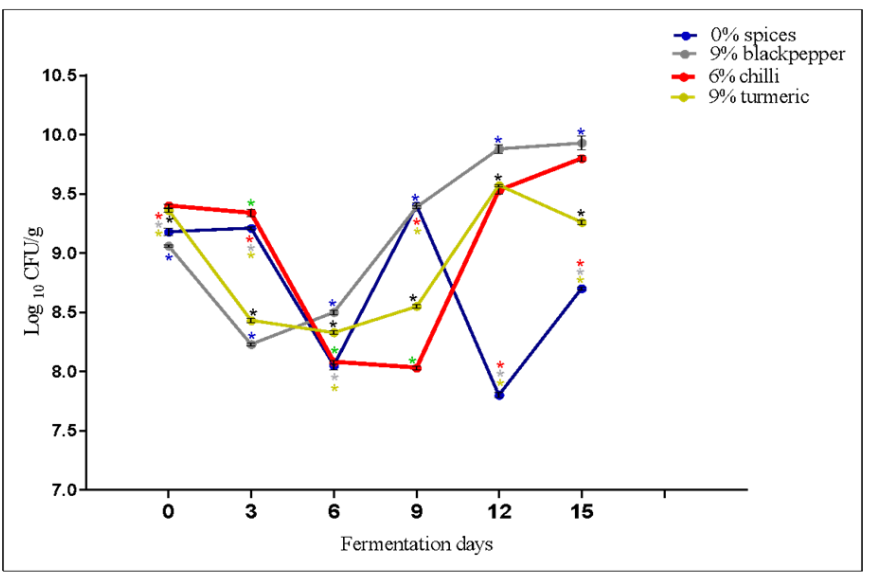

Figure 3. Growth of LAB in fermented tilapia $\left(\log _{10} \mathrm{CFU} / \mathrm{g}\right)$ incorporated without spices, 9\% black pepper, $6 \%$ chilli and $9 \%$ turmeric on M17 agar. Data are mean of triplicated $(n=3)$ indicating standard error (SE)

Figure 3 shows the microbial count of fermented tilapia incorporated without spices, $9 \%$ black pepper, $6 \%$ chilli and 9\% turmeric on M17 agar.

Fermented fish with $6 \%$ chilli showed the highest microbial count on day 0 and day 3 of the fermentation period. However, for the remaining days of the fermentation period, black pepper showed the highest microbial count. The highest LAB count can be observed on day 15 of the fermentation period on fermented tilapia incorporated with black pepper for M17 agar.

Figure 4 shows the microbial count of fermented tilapia incorporated without spices, $9 \%$ black pepper, $6 \%$ 
chilli and 9\% turmeric on Tomato Juice agar.

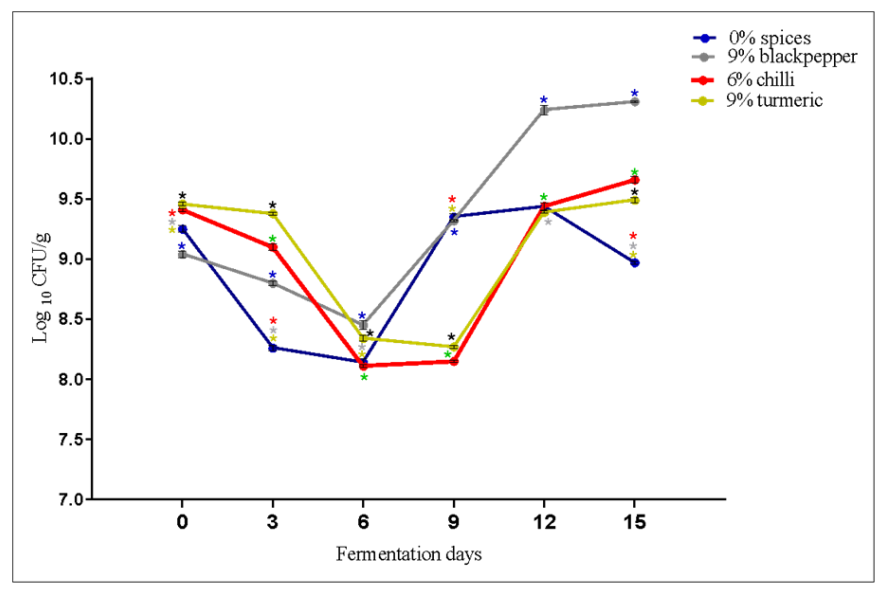

Figure 4. Growth of LAB in fermented tilapia $\left(\log _{10} \mathrm{CFU} / \mathrm{g}\right)$ incorporated without spices, $9 \%$ black pepper, $6 \%$ chilli and $9 \%$ turmeric on Tomato Juice agar. Data are mean of triplicated $(n=3)$ indicating standard error $(\mathrm{SE})$

From day 0 until day 3 , fermented tilapia incorporated with turmeric showed the highest number of microbial counts. From day 6 until the end of the fermentation period, fermented tilapia incorporated with black pepper showed the highest number of microbial counts. LAB count can be observed to have the highest count in fermented tilapia incorporated with black pepper on day 15 of the fermentation on Tomato Juice agar. The LAB from fermented fish incorporated with black pepper showed the highest growth meanwhile most of the LAB growth was the highest at the end of the fermentation period ( 9 to 15 days of fermentation).

\subsection{Screening for antimicrobial activity against various foodborne pathogens by well diffusion method}

From the isolation procedure, 32 isolates of LAB which have been confirmed as Gram-positive and catalase and oxidase negative were further tested for their antimicrobial activity.

From Table 2, the antimicrobial activity of isolated LAB against Bacillus cereus. The highest antimicrobial activity recorded was $26.00 \pm 0.58 \mathrm{~mm}$ that recorded from LAB isolated from fermented fish incorporated with $9 \%$ black pepper on M17 agar. Meanwhile, there is no antimicrobial activity recorded from isolated $\mathrm{LAB}$ from Fermented fish incorporated with 9\% turmeric.

Table 3 shows the antimicrobial activity of isolated LAB against Staphylococcus aureus. The highest antimicrobial activity was $14.00 \pm 0.58 \mathrm{~mm}$ was from LAB isolated from fermented fish incorporated with $6 \%$ chilli on M17 agar. While the lowest $(8.33 \pm 0.89 \mathrm{~mm})$ was from control on MRS+CaCO 3 agar. $\mathrm{LAB}$ isolated from fermented fish incorporated with 9\% turmeric showed no antimicrobial activity for all types of media.

In comparison, antimicrobial activity against Escherichia coli of LAB isolated from fermented fish without spices was the highest on M17 agar as shown in Table 4. Meanwhile, the lowest antimicrobial activity was observed on LAB isolated from fermented fish incorporated with $9 \%$ black pepper on M17 agar.

Finally, Table 5 shows the highest antimicrobial activity against Salmonella enterica serovar Typhimurium can be observed from LAB isolated from fermented tilapia incorporated without spices on MRS agar. Meanwhile, the lowest was from LAB isolated from fermented fish incorporated with $6 \%$ chilli on MRS with $\mathrm{CaCO}_{3}$ agar. However, the LAB isolated from fermented fish incorporated with $9 \%$ turmeric shows no antimicrobial activity at all.

From the results obtained, it was proven that $\mathrm{LAB}$ was the dominant bacteria found in fermented food as

Table 2. The antimicrobial activity of isolated LAB against Bacillus cereus of day 15 of fermentation

\begin{tabular}{ccccc}
\hline \multirow{2}{*}{ Media } & \multicolumn{4}{c}{ Spices } \\
\cline { 2 - 5 } & control & $9 \%$ black pepper & $6 \%$ chilli & $9 \%$ turmeric \\
\hline MRS & 0 & $25.00 \pm 0.29^{\mathrm{A}}$ & 0 & 0 \\
M17 & 0 & $26.00 \pm 0.58^{\mathrm{B}}$ & 0 & 0 \\
MRS+CaCO $_{3}$ & $25.00 \pm 0.29^{\mathrm{Aa}}$ & 0 & $18.00 \pm 0.29^{\mathrm{b}}$ & 0 \\
Tomato Juice & $17.00 \pm 0.58^{\mathrm{B}}$ & 0 & 0 & 0
\end{tabular}

Values are expressed as mean \pm S.E $(\mathrm{mm})$ of 3 replicates. Values with different lowercase superscript and uppercase superscript within the row and column, respectively are significantly different at $\mathrm{P}<0.05$.

Table 3. The antimicrobial activity of isolated LAB against Staphylococcus aureus of day 15 of fermentation

\begin{tabular}{ccccc}
\hline \multirow{2}{*}{ Media } & \multicolumn{4}{c}{ Spices } \\
\cline { 2 - 5 } & control & $9 \%$ black pepper & $6 \%$ chilli & $9 \%$ turmeric \\
\hline MRS & 0 & 0 & 0 & 0 \\
M17 & $8.37 \pm 0.88^{\mathrm{Aa}}$ & $11.50 \pm 0.29^{\mathrm{b}}$ & $14.00 \pm 0.58^{\mathrm{c}}$ & 0 \\
$\mathrm{MRS}^{\mathrm{C} C a C O} \mathrm{Ca}_{3}$ & $8.33 \pm 0.89^{\mathrm{A}}$ & 0 & 0 & 0 \\
Tomato Juice & $10.83 \pm 0.44^{\mathrm{B}}$ & 0 & 0 & 0 \\
\hline
\end{tabular}

Values are expressed as mean \pm S.E $(\mathrm{mm})$ of 3 replicates. Values with different lowercase superscript and uppercase superscript within the row and column, respectively are significantly different at $\mathrm{P}<0.05$. 
Table 4. The antimicrobial activity of isolated LAB against Escherichia coli of day 15 of fermentation

\begin{tabular}{ccccc}
\hline \multirow{2}{*}{ Media } & \multicolumn{4}{c}{ Spices } \\
\cline { 2 - 5 } & control & $9 \%$ black pepper & $6 \%$ chilli & $9 \%$ turmeric \\
\hline MRS & 0 & $13.10 \pm 0.21^{\mathrm{Aa}}$ & $14.50 \pm 0.77^{\mathrm{Ab}}$ & $12.43 \pm 0.23^{\mathrm{Aa}}$ \\
$\mathrm{M} 17$ & $16.43 \pm 0.23^{\mathrm{Aa}}$ & $12.10 \pm 0.21^{\mathrm{Bb}}$ & 0 & $15.43 \pm 0.30^{\mathrm{Bc}}$ \\
$\mathrm{MRS}^{\mathrm{C} C a C O} \mathrm{CO}_{3}$ & $15.00 \pm 0.35^{\mathrm{Ba}}$ & 0 & $12.43 \pm 0.30^{\mathrm{Bb}}$ & 0 \\
Tomato Juice & 0 & 0 & 0 & 0 \\
\hline
\end{tabular}

Values are expressed as mean \pm S.E (mm) of 3 replicates. Values with different lowercase superscript and uppercase superscript within the row and column, respectively are significantly different at $\mathrm{P}<0.05$.

Table 5. The antimicrobial activity of isolated LAB against Salmonella enterica serovar Typhimurium of day 15 of fermentation

\begin{tabular}{|c|c|c|c|c|}
\hline \multirow{2}{*}{ Media } & \multicolumn{4}{|c|}{ Spices } \\
\hline & control & $9 \%$ black pepper & $6 \%$ chilli & $9 \%$ turmeric \\
\hline MRS & $19.87 \pm 0.19^{\mathrm{Aa}}$ & $14.93 \pm 0.23^{\mathrm{Ab}}$ & $14.20 \pm 0.15^{\mathrm{Ab}}$ & 0 \\
\hline M17 & 0 & $11.50 \pm 0.36^{\mathrm{B}}$ & 0 & 0 \\
\hline $\mathrm{MRS}+\mathrm{CaCO}_{3}$ & $18.87 \pm 0.49^{\mathrm{Ba}}$ & 0 & $10.87 \pm 0.58^{\mathrm{Bb}}$ & 0 \\
\hline Tomato Juice & $12.50 \pm 0.23^{\mathrm{C}}$ & 0 & 0 & 0 \\
\hline
\end{tabular}

Values are expressed as mean \pm S.E $(\mathrm{mm})$ of 3 replicates. Values with different lowercase superscript and uppercase superscript within the row and column, respectively are significantly different at $\mathrm{P}<0.05$.

agreed by Hwanhlem et al. (2011) and Grosu-Tudor et al. (2014) extensively report that LAB was a dominant bacteria found in fermented meat, fish, fruits, vegetables and dairy products. The fermented tilapia incorporated with black pepper showed the highest number of LAB, followed by chilli and turmeric. The LAB count was the highest at the end of the fermentation period and might be due to the production of lactic acid from LAB during the fermentation process. The lactic acid decreased the $\mathrm{pH}$ of the product thereby decreasing the number of other microbes. The typical acid-forming bacteria rapidly increased in number, becoming the predominant microbes after fermentation had started and reached their maximum density at the end of the fermentation (Hugas, 1998; Ngasotter et al., 2020).

The LAB produces a variety of antibacterial substances including bacteriocins to inhibit the growth of pathogenic bacteria (Ekhay et al., 2013; Yasmeen et al., 2015). Moreover, as reported by Rohmah et al. (2012), the LAB (Lactobacillus casei and L. paracasei) isolated from fermented fish in Malaysia shows an antimicrobial effect against $B$. cereus, S. aureus, S. enterica, Listeria monocytogenes and E. coli.

All spices used in this study are well-known sources that can be used as antimicrobials. For example, turmeric is well-known as an antimicrobial and antiseptic agent. De et al. (1999) reported that the essential oil from turmeric has an antimicrobial property against pathogenic bacteria and fungi. Chilli has also been found to possess antimicrobial properties due to the capsaicin from chilli that acts as a potent inhibitor of Helicobacter pylori. Moreover, the essential oil of black pepper can inhibit the growth and germination of Clostridium botulinum (Hariri and Ghiasvand, 2016). Black pepper is also rich in glutathione peroxidase and glucose-6- phosphate dehydrogenase (Karthikeyan and Rani, 2003), and can damage the membrane of bacteria to avoid its growth (Karsha and Lakshmi, 2010).

Some spices including black pepper, chilli and turmeric in the form of powder, extract or extracted oil is known to control microbial spoilage of food (Karapinar and Aktug, 1987; Meena and Sethi, 1994; De and De, 2019). Previous studies also showed that a lot of different types of spices have antimicrobial effect. Clove, oregano and thyme showed inhibitory effect against $E$. coli (Moriera et al., 2007). Conner and Beuchat (1984) suggested that the antimicrobial activity of the essential oils of herbs and spices could be the result of damage to enzymatic cell systems, including those associated with energy production and synthesis of structural compounds.

The incorporation of spices and fermented fish do not affect the growth of LAB because our findings did not show any major inhibition growth of LAB during the 15 days of the fermentation period. The application of extremely high concentration of phenolic compounds could inhibit the LAB growth as previously reported by Stead (1993) but the report from Kittisakulnam et al. (2016) showed that appropriate amounts of spices added do not interfere with $\mathrm{LAB}$ production in meat products incorporated with spices.

The combination of the LAB from fermented tilapia with the spices (black pepper, chilli and turmeric) shows high antimicrobial activities against $B$. cereus, $S$. aureus, E. coli, and S. enterica ser. Typhimurium. However, the fermented fish without the spices also displayed a high antimicrobial effect in several stages of fermentation towards the foodborne bacteria. According to O'Bryan et al. (2015), antimicrobial compounds produced by LAB during fermentation also inhibited the growth of inactive 
spoilage and pathogenic microorganisms. Organic acids such as lactic, acetic and propionic acids provide an acidic environment and inhibit the growth of acidsensitive spoilage microorganisms. Acids can directly act upon the cell walls of Gram-negative bacteria and cause the failure of proton motive forces, reducing the colonization of pathogenic bacteria (Dittoe et al., 2018). The salt content in fermented fish also helps to enhance the flavour by activating some of the enzymes inherent in the fish's flesh or the microorganisms (Mariutti and Bragagnolo, 2017).

Fermented fish incorporated with spices is the best method to preserve fresh products due to the combination of both salt and spices that have dual effects which result in lowering the water activity level and having a specific inhibitory effect on the growth of some microorganisms. The spices have the capacity to migrate inside the fish, resulting in water oozing out of the fish and decreasing moisture (Horner, 1997; Alex and Eagappan, 2017). This decrease in moisture leads to an increase in spice content and consequently extends the shelf life of the product (Lopez, 1987; Itou and Akabane, 2000). Spices help slow down the microbial growth and eventually totally suppresses it (Souza et al., 2005; Torres et al., 2015). In agreement with previous study from Geremew et al. (2015), the combined effect of spices incorporated with the fermented goods can also be seen in the production of traditional cottage cheese (metata ayib) as LAB antimicrobial activity had reduced the risk of spoilage and pathogenesis. The use of spices would decrease the chances of food poisoning, food spoilage and increase food shelf life. Other than that, metata ayib also exhibited antimicrobial activity against pathogenic test strains.

Different selective media were used in this study in order to increase the chances of LAB species to grow in the fermented fish. Tomato juice agar is recommended for the cultivation and enumeration of Lactobacilli (MacFaddin, 1985). MRS in an improved media from Tomato Juice Agar which developed by de Man, Rogosa and Sharpe that designed to encourage the growth of the lactic acid bacteria which includes species of the following genera: Lactobacillus, Streptococcus, Pediococcus and Leuconostoc (Lankaputhra et al., 1996). The addition of calcium carbonate in MRS Agar as reported by Hwanhlem et al. (2011) and Aween et al. (2012) was an excellent indicator for acid-producing strains since it dissolved when interacting with acid then a clear zone is observed. Another media, M17 Agar was used as it is suitable for the growth and enumeration of lactic streptococci and their bacteriophages (Terzaghi and Sandine, 1975).
Other than acting as a very good antimicrobial agent for fermented fish, spices are also used for flavouring foods and bringing a distinguished flavour to each food style that gives culinary identity (Exploratorium, 2013; Torres et al., 2015). Flavour given by spices is due to a certain family of chemicals such as phenylpropanoids, monoterpenes and other phenol compounds (Peter and Shylaja, 2012; Torres et al., 2015)

\section{Conclusion}

The fermented tilapia incorporated with black pepper, chilli and turmeric show no significant effect on the growth of LAB and the highest growth of LAB was observed in the later stages of fermentation in relation to different media used. Only MRS, MRS with $\mathrm{CaCO}_{3}$ and M17 agar show high microbial activity against the foodborne pathogens. Other than that, the incorporation of fermented tilapia fish with black pepper and chilli show antimicrobial activity, however, turmeric was not given an antimicrobial activity for pathogens except for E. coli. Although the antimicrobial effect of LAB without the addition of spices also can be observed when a combination of LAB and spices were used, the antimicrobial effect was the highest against $B$. cereus. Obtaining antimicrobials from natural sources such as spices is a good alternative for the preservation of fresh products and also give an extra taste to the fermented fish. Further research can be conducted to find out the antimicrobial activity of other Malaysian spices as well as the mixture and combination of different spices.

\section{Acknowledgements}

This work was financially supported by the Ministry of Higher Education, Malaysia under Fundamental Research Grant Scheme (Vot. No. 59269). Special thanks to Assoc. Prof. Dr. Zaiton Hassan for mentoring this project.

\section{References}

Ahmad, F.T., Lani, M.N., Nazari, S.A., Hajar, N.H.M., Hasan, K.N.A.M., Razak, S.B.A. and Hassan, Z. (2019). Antioxidant and antimicrobial properties of honey propolis and bee bread of stingless bee (Geniotrigona thoracica). Asian Journal of Agriculture and Biology, 7(Special Issue), 76-85.

Alex, T. and Eagappan, K. (2017). An empirical study on the effect of spices and herbs in the shelf life of dried Indian anchovy fish. Journal of Agriculture and Veterinary Science, 10(3), 1-7. https:// doi.org/10.9790/2380-1003010107

Anand, S.P. and Sati, N. (2013). Artificial preservatives and their harmful effects: Looking toward nature for 
safer alternatives International Journal of Pharmaceutical Science and Research, 4(7), 24962501.

Arul, K.T. and Saravanan, S. (2011). Assessment of contamination in chicken meat by food- borne Staphylococcus aureus. International Journal of Research Pure and Applied Microbiology, 1, 59-60.

Aslim, B., Yukesekdag, Z.N., Sarikaya, E. and Beyatli, Y. (2005). Determination of the bacteriocin-like substances produced by some lactic acid bacteria isolated from Turkish dairy products. Food Science and Technology, 38(6), 691-694. https:// doi.org/10.1016/j.lwt.2004.08.001

Attalla, R.F. (2001). The use of fish meal replaces in fresh water aqua-feeds. Faculty of Sciences. Egypt: Zagazig University, PhD Dissertation.

Awang, C.R. (2001). MARDI. Processing Technology for Fermented Tilapia (pekasam Tilapia). Retrieved from http://agromedia.mardi.gov.my/magritech/ tech_detail_fdscience.php?id=369.

Aween, M.M., Hassan, Z., Muhialdin, B.J., Eljamel, Y.A., Al-Mabrok, A.S. and Lani, M.N. (2012). Antibacterial activity of Lactobacillus acidophilus strains isolated from honey marketed in Malaysia against selected multiple antibiotic resistant (MAR) Gram-positive bacteria. Journal of Food Science, 77 (7), M364-371. https://doi.org/10.1111/j.17503841.2012.02776.x

Aziz, M. and Karboune, S. (2016). Natural Antimicrobial/Antioxidant Agents in Meat and Poultry Products as Well as Fruits and Vegetables: A Review. Critical Reviews in Food Science and Nutrition, 58(3), 486-511. https:// doi.org/10.1080/10408398.2016.1194256

Barbudhe, B., Swain, B.K., Chakurkar, E.B. and Sundaram, R.N.S. (2003). Microbial quality of poultry meat with special reference to Listeria monocytogenes. Indian Journal of Poultry Science, 38(3), 305-307.

Brewer, M.S. (2011). Natural antioxidants: sources, compounds, mechanisms of action, and potential applications. Comprehensive Reviews in Food Science and Food Safety, 10(4), 221-247. https:// doi.org/10.1111/j.1541-4337.2011.00156.x

Conner, D.E. and Beuchat, L.R. (1984). Effects of essential oils from plants on growth of food spoilage yeasts. Journal of Food Science, 49, 4290434. https://doi.org/10.1111/j.1365-2621.1984.tb12437.x

De, M., De, A.K. and Banerjee, A. (1999). Antimicrobial screening of some Indian spices. Phytotherapy Research, 13(7), 616-618. https://doi.org/10.1002/ (SICI)1099-1573(199911)13:7<616::AID-
PTR475>3.0.CO;2-V

De, A.K. and De, M. (2019). Functional and therapeutic applications of some important spices. In Singh, R.B., Watson, R.R. and Takahashi, T. (Ed.) The Role of Functional Food Security in Global Health, p. 499 -510. USA: Academic Press. https://doi.org/10.1016/ B978-0-12-813148-0.00029-3

Dittoe, D.K., Ricke, S.C. and Kiess, A.S. (2018). Organic acids and potential for modifying the avian gastrointestinal tract and reducing pathogens and disease. Frontiers in Veterinary Science, 5, 216. https://doi.org/10.3389/fvets.2018.00216

Ekhay, O., Ouhsassi, M., Abdeltif, E.H., Idaomar, M. and Abrini, J. (2013). Optimisation of bacteriocinlike production by Enterococcus durans E204 isolated from camel milk of Morocco. Current Research in Microbiology Biotechnology, 1, 155159.

Ezzat, M., Zare, D., Karim, R. and Ghazali, H. (2015). Trans-and cis-urocanic acid, biogenic amine and amino acid contents in Ikan pekasam (fermented fish) produced from Javanese carp (Puntius gonionotus) and black tilapia (Oreochromis mossambicus). Food Chemistry, 172, 893-899. https://doi.org/10.1016/j.foodchem.2014.09.158

Exploratorium. (2013). Spice blends of the World Science cooking California USA. Retrieved from http://www.exploratorium.edu/cooking/seasoning/ map/spicemap.htmL

Fernandez-Lopez, J., Zhi, N., Aleson-Carbonell, L., Perez-Alvarez, J.A. and Kuri, V. (2005). Antioxidant and antibacterial activities of natural extracts: Application in beef meatballs. Meat Science, 69, 371 -380. https://doi.org/10.1016/j.meatsci.2004.08.004

Food and Agriculture Organisation/World Health Organisation. (2001). Evaluation of health and nutritional properties of probiotics in food including powdered milk and live lactic acid bacteria. Report of the Food and Agriculture Organization of the United Nations and World Health Organisation Workshop. Geneva: FAO and WHO.

Geremew, T., Kebede, A. and Andualem, B. (2015). The role of spices and lactic acid bacteria as antimicrobial agent to extend the shelf life of metata ayib (traditional Ethiopian spiced fermented cottage cheese). Journal of Food Science Technology, 52(9), 5661-5670. https://doi.org/10.1007/s13197-014-1694 $-\mathrm{y}$

Giri, A., Osako, A., Okamoto, A. and Ohshima, T. (2010). Olfactometric characterisation of aroma active compounds in fermented fish paste in comparison with fish sauce, fermented soy paste and 
sauce products. Food Research International, 43(4), 1027-1040. https://doi.org/10.1016/ j.foodres.2010.01.012

Grosu-Tudor, S.S., Stancu, M.M., Pelinescu, D. and Zamfir, M. (2014). Characterisation of some bacteriocins produced by lactic acid bacteria isolated from fermented foods. World Journal of Microbiology and Biotechnology, 30, 2459-2469. https://doi.org/10.1007/s11274-014-1671-7

Hamli, H., Idris, M.H. and Wong, S.K. (2013). Effect of fermented kitchen waste on Tilapia (Oreochromis niloticus) growth performance and water quality as water additive. Journal of Biological Sciences, 13(6), 559-562. https://doi.org/10.3923/jbs.2013.559.562

Hariri, M. and Ghiasvand, R. (2016). Cinnamon and chronic diseases. In Gupta, S., Prasad, S. and Aggarwal, B. (Eds.). Advances in Experimental Medicine and Biology. Vol. 929, p. 1-24. Cham, The Netherlands: Springer. https://doi.org/10.1007/978-3 -319-41342-6_1

Hernández, L., Aguirre, Y.B., Nevárez, G.V., Gutierrez, N. and Salas, E. (2011). Use of essential oils and extracts from spices in meat protection. Journal of Food Science Technology, 51(5), 957-963. https:// doi.org/10.1007/s13197-011-0598-3

Horner, W.F.A. (1997). Preservation of fish by curing (drying, salting and smoking). In Fish Processing Technology. p. 31-71. Blackie Academic and Professionals, New York. https:// doi.org/10.1007/978-1-4613-1113-3_2

Hugas, M. (1998). Bacteriocinogenic lactic acid bacteria for the biopreservation of meat and meat products. Meat Science, 49(Supplement 1), S139-S150. https:// doi.org/10.1016/S0309-1740(98)90044-4

Hwanhlem, N., Buradaleng, S., Wattanachant, S., Benjakul, S., Tani, A. and Maneerat, S. (2011). Isolation and screening of lactic acid bacteria from Thai traditional fermented fish (Plasom) and production of Plasom from selected strains. Food Control, 22(3-4), 401-407. https://doi.org/10.1016/ j.foodcont.2010.09.010

Itou, K. and Akabane, Y. (2000). Changes in general ingredients and extract ingredients during the Masaba Heshiko manufacturing process. Journal of the Japanese Society of Fisheries Science, 66(6), 1051-1058. https://doi.org/10.2331/suisan.66.1051

Jiang, Y., Wu, N.A., Fu, Y.J., Wang, W., Luo, M., Zhao, C.J., Zu, Y.G. and Liu, X.L. (2011). Chemical composition and antimicrobial activity of the essential oil of rosemary. Environmental Toxicology and Pharmacology, 32(1), 63-68. https:// doi.org/10.1016/j.etap.2011.03.011
Karapinar, M. and Aktug, S.E. (1987). Inhibition of food borne pathogens by thymol, eugenol, menthol and anethole. International Journal of Food Microbiology, 4(2),161-166. https:// doi.org/10.1016/0168-1605(87)90023-7

Karsha, P.V. and Lakshmi, O. (2010). Antibacterial activity of black pepper (Piper nigrum Linn.) with special reference to its mode of action on bacteria. Indian Journal of Natural Products and Resources, 1 (2), 213-215.

Karthikeyan, J. and Rani, P. (2003). Enzymatic and nonenzymatic antioxidants in selected Piper species. Indian Journal of Experimental Biology, 41,135140.

Kittisakulnam, S., Saetae, D. and Suntornsuk, W. (2016). Antioxidant and antibacterial activities of spices traditionally used in fermented meat products. Journal of Food Processing and Preservation, 41(4), 13004. https://doi.org/10.1111/jfpp.13004

Knechtges, P.L. (2012). Food safety: Theory and practice. Burlington, USA: Jones and Bartlett Learning.

Lankaputhra, W.E.V., Shah, N.P. and Britz, M.L. (1996). Evaluation of media for selective enumeration of Lactobacillus acidophilus and Bifidobacterium spp. Food Australia, 48, 113-118.

Leroy, F. and De Vuyst, L. (2004). Lactic acid bacteria as functional starter cultures for the food fermentation industry. Trends Food Science and Technology, 15(2), 67-78. https://doi.org/10.1016/ j.tifs.2003.09.004

Liasi, S.A., Azmi, T.I., Hassan, M.D., Shuhaimi, M., Rosfarizan, M. and Ariff, A.B. (2009). Antimicrobial activity and antibiotic sensitivity of three isolates of lactic acid bacteria from fermented fish product, Budu. Malaysian Journal of Microbiology, 5(1), 3337. https://doi.org/10.21161/mjm.15008

Lopetcharat, K.Y.J., Choi, J., Park, W. and Daeschel, M.A. (2001). Fish sauce products and manufacturing: A review. Food Reviews International, 17(1), 65-88. https://doi.org/10.1081/ FRI-100000515

Lopez, A. (1987). A complete course in canning Book: II and III. 12th ed. Baltimore, USA: The canning Trade Inc.

MacFaddin, J.F. (1985). Media for isolation-cultivationidentification-maintenance of medical bacteria. Vol. 1, Baltimore, USA: Williams and Wilkins.

Mariutti, L.R. and Bragagnolo, N. (2017). Influence of salt on lipid oxidation in meat and seafood products: A review. Food Research International, 94, 90-100. https://doi.org/10.1016/j.foodres.2017.02.003 
Meena, M.R. and Sethi, V.J. (1994). Antimicrobial activity of essential oil from spices. Food Science Technology, 31, 68-71.

Moriera, M.R., Ponce, A.G., Del Valle, C.E. and Roura, S. (2007). Effects of clove and tea tree oils on Escherichia coli $\mathrm{O} 157: \mathrm{H} 7$ in blanching spinach and minced cooked beef. Journal of Food Processing and Preservation, 31(4), 379-391. https:// doi.org/10.1111/j.1745-4549.2007.00135.x

Mouritsen, O.G., Duelund, L., Calleja, G. and Frost, M.B. (2017). Flavour of fermented fish, insect, game, and pea sauces: Garum revisited. International Journal of Gastronomy and Food Science, 9, 16-28. https://doi.org/10.1016/ j.ijgfs.2017.05.002

Nicorescu, I., Nguyen, B., Moreau-Ferret, M., Agoulon, A., Chevalier, S. and Orange, N. (2013). Pulsed light inactivation of Bacillus subtilis vegetative cells in suspensions and spices. Food Control, 31(1), 151157. https://doi.org/10.1016/j.foodcont.2012.09.047

Ngasotter, S., Mukherjee, S. and Waikhom, D. (2020). Diversity of Lactic Acid Bacteria (LAB) in fermented fish products: A review. International Journal of Current Microbiology and Applied Science, 9(5), 2238-2249. https://doi.org/10.20546/ ijcmas.2020.905.255

Noor 'Izzati, H. (2013). Effects of selected spices on shelf life, microbiological quality and sensory acceptance of fermented Tilapia. Terengganu, Malaysia: Universiti Malaysia Terengganu, BSc. Thesis.

O'Bryan, C., Crandall, P., Ricke, S. and Ndahetuye, J. (2015). Lactic acid bacteria (LAB) as antimicrobials in food products: Types and mechanisms of action. In Taylor, T.M. (Ed.) Handbook of Natural Antimicrobials for Food Safety and Quality, p. 117129. USA: Academic Press https://doi.org/10.1016/ B978-1-78242-034-7.00006-2

Paludan-Müller, C., Madsen, M., Sophanodora, P., Gram, L. and Møller, P.L. (2002). Genotypic and phenotypic characterization of garlic-fermenting lactic acid bacteria isolated from som-fak, a Thai low -salt fermented fish product. International Journal of Food Microbiology, 73(1), 61-70. https:// doi.org/10.1016/S0168-1605(01)00688-2

Panda, S.H., Ray, R.C., El Sheikha, A.F., Montet, D. and Worawattanamateekul, W. (2011). Fermented fish and fish products: An overview. Aquaculture Microbiology and Biotechnology, 2, 132-72. https:// doi.org/10.1201/b10923-7

Panthavee, W., Saithong, P. and Worawuthiyanan, N. (2007). Identification and evaluation of lactic acid bacteria for Pla-som (fermented fish) starter. In The 2nd International Conference on Fermentation Technology for Value Added Agricultural Products. 23 - 25 May. Kosa Hotel, Khon Kaen, Thailand.

Peter, K.V. and Shylaja, M.R. (2012). Introduction to herbs and spices: definitions, trade and applications. In Peter, K.V. (Ed.) The Handbook of herbs and spices. $2^{\text {nd }}$ ed., p. 1-24. USA: Woodhead Publishing. https://doi.org/10.1533/9780857095671.1

Rather, I.A., Koh, W.Y., Paek, W.K. and Lim, J. (2017). The sources of chemical contaminants in food and their health implications. Frontiers in Pharmacology, 8, 830. https://doi.org/10.3389/ fphar.2017.00830

Rohmah, A.S., Risa, N. and Puji, A. (2012). Characterisation lactic acid bacteria genus Leuconostoc from Allele Pekasam. Journal of Chemistry, 1(1), 14-20.

Salleh, W., Lani, M.N., Abdullah, W.Z.W., Chilek, T.Z.T. and Hassan, Z. (2017). A review on incidences of foodborne diseases and interventions for a better national food safety system in Malaysia. Malaysian Applied Biology, 46(3), 1-7.

Salleh, F., Lani, M.N., Chilek, T.Z.T., Kamaruding, N.A. and Ismail, N. (2021). Lactic acid bacteria producing sorbic acid and benzoic acid compounds from fermented durian flesh (Tempoyak) and their antibacterial activities against foodborne pathogenic bacteria. Applied Food Biotechnology, 8(2), 121132.https://doi.org/10.22037/afb.v8i2.32749

Solieri, L., Bianchi, A., Mottolese, G., Lemmetti, F. and Giudici, P. (2014). Tailoring the probiotic potential of non-starter Lactobacillus strains from ripened Parmigiano Reggiano cheese by in vitro screening and principal component analysis. Food Microbiology, 38, 240-249. https://doi.org/10.1016/ j.fm.2013.10.003

Souza, E.L., Montenegro, T.L., Lima, E., Trajano, V.N. and Barbosa, J.M. (2005). Antimicrobial effectiveness of spices: an approach for use in food conservation systems. Brazilian Archive of Biology and Technology, 48(4), 549-558. https:// doi.org/10.1590/S1516-89132005000500007

Stead, D. (1993). The effect of hydroxycinnamic acids on the growth of wine-spoilage lactic acid bacteria. Journal of Applied Bacteriology, 75(2), 135-141. https://doi.org/10.1111/j.1365-2672.1993.tb02758.x

Tajkarimi, M.M., Ibrahim, S.A. and Cliver, D.O. (2010). Antimicrobial herb and spice compounds in food. Food Control, 21(9), 1199-1218. https:// doi.org/10.1016/j.foodcont.2010.02.003

Terzaghi, B.E. and Sandine, W.E. (1975). Improved media for lactic streptococci and their 
bacteriophages. Applied Microbiology, 29, 807-813.

https://doi.org/10.1128/AM.29.6.807-813.1975

Torres, J.E.D.L.T., Gassara, F., Kouassi, A.P., Brar, S.K. and Belkacemi, K. (2015). Spice use in food: properties and benefits. Critical Reviews in Food Science and Nutrition, 57(6), 1-43. https:// doi.org/10.1080/10408398.2013.858235

Yasmeen, Y.A., Elyas, Y.Y., Nuha, M.E., Yousif, N.M., Isam, A. and Ahmed, M. (2015). Screening of lactic acid bacteria from Sudanese fermented foods for bacteriocin production. Journal of Microbiology Biotech Food Science, 4, 373-378. https:// doi.org/10.15414/jmbfs.2015.4.5.373-378

Yu, D., Regenstein, J.M. and Xia, W. (2018). Bio-based edible coatings for the preservation of fishery products: A review. Critical Reviews in Food Science and Nutrition, 59(15), 2481-2493. https:// doi.org/10.1080/10408398.2018.1457623

Zang, J., Xu, Y., Xia, W. and Jiang, Q. (2016). The impact of desmin on texture and water-holding capacity of ice-stored grass carp (Ctenopharyngodon idella) fillet. International Journal of Food Science and Technology, 52(2), 464 -471. https://doi.org/10.1111/ijfs.13302

Zang, J., Xu, Y., Xia, W. and Regenstein, J.M. (2020). Quality, functionality, and microbiology of fermented fish: a review. Critical Reviews in Food Science and Nutrition, 60(7), 1228-1242. https:// doi.org/10.1080/10408398.2019.1565491

Zeng, X., Xia, W., Jiang, Q. and Yang, F. (2013). Chemical and microbial properties of Chinese traditional low-salt fermented whole fish product suan yu. Food Control, 30(2), 5905. https:// doi.org/10.1016/j.foodcont.2012.07.037 